\title{
NEWYYSBKHOOL
}

digitalcommons.nyls.edu

Faculty Scholarship

Articles \& Chapters

1993

\section{Federalism Awry: The Structure of Government in the Kwazulu/Natal Constitution}

Stephen Ellmann

New York Law School, stephen.ellmann@nyls.edu

Follow this and additional works at: http://digitalcommons.nyls.edu/fac_articles_chapters

\section{Recommended Citation}

9 S. Afr. J. on Hum. Rts. 165 (1993)

This Article is brought to you for free and open access by the Faculty Scholarship at DigitalCommons@NYLS. It has been accepted for inclusion in Articles \& Chapters by an authorized administrator of DigitalCommons@NYLS. 


\title{
FEDERALISM AWRY: THE STRUCTURE OF GOVERNMENT IN THE KWAZULU/NATAL CONSTITUTION
}

\author{
Stephen EllmanN*
}

Taking South Africa by surprise, on 1 December 1992 the KwaZulu Legislative Assembly adopted a draft constitution for the as-yetnon-existent state of KwaZulu/Natal. Unanimously adopted by a oneparty legislature without public debate, ${ }^{1}$ and in such apparent haste that it is riddled with bizarre typographical and stylistic errors, ${ }^{2}$ this constitution was reportedly drafted by two Americans, one of whom defended the resulting document as being based on widespread consultations with experts and others. ${ }^{3}$ Perhaps so. Yet the constitution that emerged is, for an American, most striking not for its embodiment but for its rejection of much of what Americans have learned about constitutional structure over our two centuries of independence. If this

* BA JD (Harvard). Associate Professor of Law, New York Law School. I thank Nancy Rosenbloom for her helpful comments on this piece.

1 'Buthelezi brazens it out' Negotiation News 17 December 1992); 'Conservative US experts helped draft constitution' Weekly Mail 4-10 December 1992).

2 See eg, Constitution of the State of KwaZulu/Natal (hereafter cited as KwaZulu/Natal Constitution), arts 70 (c) and $71(\mathrm{~d})$ (both containing the same sentence: 'All political parties shall be represented in the committees of each house.'); art 82(a) (establishing a 'Privatization Commission' to 'consist of nine highly qualified and independent experts . . . three appointed by the Governor, five by the General Assemble [sic] and two by the Chamber of Commerce') (emphasis added). The initial size of the Senate also seems to have been miscalculated, see art 107 (providing for election of a Senate of 102 members by electing one Senator from every three constituencies of the House of Delegates) and art 69 (c) (providing for 350 constituencies for the House of Delegates). For other examples of mis-drafting, see arts 47, 81(b), 95(e), 102(a), and 103(b).

Presumably the reason for KwaZulu's haste was the desire of Chief Mangosuthu Buthelezi to make the draft public just as the government and the African National Congress were beginning a bilateral, confidential negotiating session. Buthelezi, however, has claimed that this timing was just 'coincidence'. See 'Buthelezi sets a course for federalism', Agence France Presse 1 December 1992 (available on NEXIS).

3 According to the Weekly Mail, the KwaZulu/Natal constitution was drafted by Professor Albert Blaustein and Dr Mario Oriani-Ambrosini. Oriani-Ambrosini is quoted as saying that '[s]ome of the best minds in the world co-operated on this, with a very long consultation with political leaders, social leaders and businessmen throughout the state'. Oriani-Ambrosini also explained that 'the reason for the lack of publicity about the constitution prior to its approval was because "we're in Africa. Most processes are not in the public eye . ..." ' Conservative US experts helped draft constitution' Weekly Mail 4-10 December 1992. 
constitution were to be enacted into law, it would debilitate the central government of a future South Africa - a result that not only ignores the judgments about the proper scope of national governmental power embodied in modern American constitutional doctrine, but resists as well insights that were apparent to the framers of our constitution in 1787 . The KwaZulu/Natal constitution is, indeed, reminiscent of the notions of interstate relations that prevailed in the United States before our constitution was adopted, in the years of the 1780s when the United States lived under the 'Articles of Confederation', a charter of government which quickly lost the support of many Americans two centuries ago and ought not to be resurrected in South Africa now.

The Articles of Confederation traced the outlines of a confederation of states which could scarcely endure each other's authority over them. 'Each State retains its sovereignty, freedom and independence, and every power, jurisdiction and right, which is not by this confederation expressly delegated to the United States', the second Article declared. ${ }^{4}$ The Articles created no independent executive branch of government, and scarcely any judicial branch. 5 Instead, what national power they conferred they placed in the hands of the Continental Congress. But the Continental Congress lacked so basic an authority as the power to tax the citizens of the country. ${ }^{6}$ It had no plenary power over interstate commerce, ${ }^{7}$ and state protectionist legislation seems to have flowered. ${ }^{8}$ Nor could it make basic decisions on issues of war and peace, or the borrowing and spending of money, without the consent of a supermajority of the states - 9 of the 13 - or authorise the making of such decisions by any executive body during the periods when Congress itself was not in session. ${ }^{9}$ Even when the Congress did act, it lacked enforcement power, for although Article XIII provided that '[e]very State shall abide by the determinations of the United States in Congress assembled, on all questions which by this confederation are submitted to them', ${ }^{10}$ no enforcement machinery was provided, and many of the states 'acted as if compliance with Article XIII was wholly optional'. ${ }^{11}$ Amendments to this structure, finally, could only be made with the agreement of 'the Legislatures of every State'. ${ }^{12}$

4 Articles of Confederation, art II. The Articles were drafted in 1777, but not ratified by the last of the original thirteen states until 1781.

5 See Articles, arts IX, $X$.

6 Articles, art VIII.

7 See Articles, art IX, para 1.

8 See Gibbons v Ogden 22 US (9 Wheat) 1, 223-26 (1824) (Johnson J, concurring); Daniel A Farber \& Suzanna Sherry A History of the American Constitution (1990) 25.

9 Articles, art IX, para 6; art X.

10 Articles, art XIII.

11 Farber \& Sherry op cit note 8 at 24.

12 Articles, art XIII. 
The Articles of Confederation failed in the eyes of many of the people who lived under them. Their failure provided part of the impetus for the framing of the constitution which the United States now has, a constitution which took care to confer legislative, executive and judicial powers on the national government, and which described the national government's powers in much more expansive terms than had the Articles. Over time, moreover, the American understanding of the powers of the nation has expanded vastly beyond what the Framers appear to have intended. In part, this change has been the result of the country's adaptation to the demands of a complex modern society, whose massive economy, swift communications and large, diverse population seem to require a large and powerful government. In part, however, this change has not been merely technological, but instead has been the result of the country's growing belief that a powerful national government could protect the people of the country from oppression, and in particular from oppression by their states. This lesson, first taught to the country as the Union Armies fought the Civil War that resulted in the freeing of the slaves, was later given constitutional expression in the Reconstruction Amendments, whose enforcement clauses provided a new and profound source of federal power. ${ }^{13}$ The KwaZulu/Natal constitution rejects the pre-eminence of the national government of the modern United States (and many other contemporary nations) - but it also rejects the vision of a limited, yet still powerful, national government which the United States endorsed two centuries ago. A future South Africa may need a measure of regional autonomy, which the KwaZulu/Natal constitution would protect with a vengeance; but it will also need an effective national government, and no such government could emerge under this constitution. In what follows, we will examine the approach the KwaZulu/Natal constitution takes, both in its general emphasis on state sovereignty and in the specific allocations of powers which it envisages. Before we turn to this constitution, however, it will be helpful to look briefly at the stance on national power taken by the United States constitution.

The United States constitution begins by declaring that it is the work of 'We the People of the United States'. In one of the most important of the decisions of the early Supreme Court, Chief Justice Marshall insisted that the constitution 'proceeds directly from the people' and 'is [in the words of the Preamble] "ordained and established" in the name of the people'. ${ }^{14}$ Because the people of the United States created the national government, Marshall maintained, it was fallacious to assert, as one party (the state of Maryland) had, that ' $[t]$ he powers of the general government . . . are delegated by the States, who alone are truly sovereign; and must be

13 The Reconstruction Amendments were the Thirteenth (prohibiting slavery), the Fourteenth (securing rights of due process and equal protection against the states), and the Fifteenth (prohibiting denial of the right to vote on the basis of race).

14 McCulloch v Maryland 17 US (4 Wheat) 316, 403 (1819). 
exercised in subordination to the States, who alone possess supreme dominion' ${ }^{15}$ Three years earlier, in another of the foundational cases of American constitutional law, Justice Story had insisted that the Supreme Court had the power to review and correct the judgments of state supreme courts, despite the claim that such authority impinged on state sovereignty. Story wrote that '[i]t is a mistake that the constitution was not designed to operate upon states, in their corporate capacities. It is crowded with provisions which restrain or annul the sovereignty of the states in some of the highest branches of their prerogatives'. ${ }^{16}$ For Story and Marshall, the idea that the federal government was 'supreme within its sphere of action' was essential, ${ }^{17}$ and this claim of supremacy found direct textual support in the new constitution's 'supremacy clause', which declared that:

'This Constitution, and the Laws of the United States which shall be made in Pursuance thereof . . . shall be the supreme Law of the Land; and the Judges in every State shall be bound thereby, any Thing in the Constitution or Laws of any State to the Contrary notwithstanding.' 18

It remained, of course, to determine just what sphere of action the constitution did entrust to the national government, and by no means everyone agreed with Marshall and Story in their answers to this question - but their position has stood the test of time, and (in the Civil War) of arms.

The tone of the KwaZulu/Natal constitution on the issue of sovereignty could hardly be more different. Whether or not this constitution was meant as an implicit threat of secession, it certainly outlines a relationship between state and nation in which state sovereignty is intensely and repeatedly insisted upon. This stance was evident in Chief Buthelezi's statement in early December 1992, that '[i]t is intended that, once ratified by the electorate of KwaZulu/Natal, the new constitution will stand in force, regardless of the direction taken by the constitutional process of South Africa' ${ }^{19}$ But the sentiment is no less apparent in the draft constitution itself. Article 3 of this draft announces, under the title, 'Relationship with the Federal Republic of South Africa' (a relationship with an entity that does not, and may never, exist):

'The State of KwaZulu/Natal is a sovereign member state of the Federal Republic of South Africa. The State of KwaZulu/Natal recognizes its obligations toward the Federal Republic of South Africa and the other member states of the Federal Republic of South Africa in so far as they do not infringe upon the rights, powers and liberties guaranteed

15 Ibid at 402 .

16 Martin v Hunter's Lessee 14 US (1 Wheat) 304, 343 (1816).

17 McCulloch v Maryland supra note 14 at 405.

18 US Constitution, art VI, para 2.

19 John Carlin 'Buthelezi says he may break away from SA' The Independent 2 December 1992 at 13 (available on NEXIS). 
by this constitution to the citizens of Natal/KwaZulu [sic] and to the State of $\mathrm{KwaZulu/Natal.} \mathrm{The} \mathrm{sovereignty} \mathrm{of} \mathrm{the} \mathrm{State} \mathrm{of} \mathrm{KwaZulu/Natal} \mathrm{as} \mathrm{asserted} \mathrm{under} \mathrm{this}$ constitution is indivisible, inalienable and untransferable. ${ }^{20}$

In section after section, the KwaZulu/Natal constitution reiterates this claim of sovereign power. Not surprisingly, where the United States constitution insists on the supremacy of national law, the KwaZulu/Natal constitution declares itself 'the supreme law of the State', and 'recognize[s]' national law only 'in so far as . . . not inconsistent with this constitution'. ${ }^{21}$ Everyone who holds office in KwaZulu/Natal must 'take an oath or a solemn affirmation to uphold and defend this constitution'22 - potentially a striking contrast to the United States constitution, which requires all federal and state officeholders to "be bound by Oath or Affirmation, to support this [national] Constitution'. ${ }^{23}$

Lest there be any doubt, another section declares that '[n]o power of the Federal Republic of South Africa shall be legitimately exercised and valid in the State of KwaZulu/Natal if inconsistent with the principles and provisions of this constitution'. ${ }^{24} \mathrm{KwaZulu} /$ Natal's Constitutional Court is given the power to declare 'the illegitimacy within the State of actions or legislation of the Federal Republic of South Africa' ${ }^{25}$ in the mangled syntax of still another provision, this court's decisions 'shall be [ie, make] ineffective in the territory of the State any action or law of the Federal Republic of South Africa which is in conflict with this constitution' ${ }^{26}$ The court's jurisdiction to make such pronouncements is labelled 'exclusive' - exclusive, perhaps, of even national courts' purview. ${ }^{27}$

Nor is KwaZulu/Natal's assertion of sovereign authority limited to declarations of power and provisions for judicial enforcement. A series of other sections of the constitution set out to enhance the status of KwaZulu/Natal in ways that would block - potentially even by force of arms - the aspirations of a national government. Since power does ultimately grow in good measure out of the barrel of a gun, the

$20 \mathrm{KwaZulu} /$ Natal Constitution, art 3.

$21 \mathrm{KwaZulu} / \mathrm{Natal}$ Constitution, arts 14, 12.

$22 \mathrm{KwaZulu} / \mathrm{Natal}$ Constitution, art 60.

23 US Constitution, art VI, para 3.

$24 \mathrm{KwaZulu} /$ Natal Constitution, art 67(c).

$25 \mathrm{KwaZulu} /$ Natal Constitution, art 102(b).

26 KwaZulu/Natal Constitution, art 102(d). The new state could also repudiate actions of the past national governments, under art 110 .

27 See KwaZulu/Natal Constitution, art 100, which gives the Constitutional Court 'original and exclusive jurisdiction' of, among other cases, the 'resolution of disputes on the legitimacy of the exercise within the territory of the State of federal powers in matters reserved to the exclusive jurisdiction of the Federal Republic of South Africa'. Elsewhere, in art 67(a), KwaZulu/Natal 'recognizes' the national government's power 'to exercise exclusive . . . judicial functions . . . in . . . organization and administration of the federal system of justice in the subject matters of federal prerogative' (emphasis added). 
constitution's provisions on military matters deserve especially careful study.

As it happens, this constitution pays close attention to these matters, in provisions that both restrict the national government's ability to work its will and arm the state of KwaZulu/Natal. National military power was a matter of concern to the citizens of the early United States as well, ${ }^{28}$ but the provisions of the KwaZulu/Natal constitution tilt the balance of state as opposed to national military power in favour of the states to a degree that may not have been contemplated in the United States even in the late eighteenth century, and that is completely inconsistent with the modern American recognition of 'the supremacy of federal power in the area of military affairs'. ${ }^{29}$ Thus one KwaZulu/Natal provision declares that '[n]o Federal armed forces or armed forces of other states may enter or be stationed in the State of KwaZulu/Natal without the approval of the State' 30 - a limit with no parallel in the United States constitution. ${ }^{31}$ Another provides that every citizen has 'the sacred duty to defend the territory of the State'; $; 2$ it goes on to announce a comparable duty to protect the territory of the nation against 'any external enemy', but only 'when so required' - a qualification which at least bespeaks a greater enthusiasm for defending the state than the nation. ${ }^{33}$

One way that KwaZulu/Natal will defend its territory is presumably through its militia. Service in this militia can be made compulsory, ${ }^{34}$ a power which might be employed to establish a standing state army under the title of 'militia'; there is no provision here, as there is in the United States constitution, expressly forbidding the states, absent congressional consent, to 'keep Troops, or Ships of War in time of Peace'. ${ }^{35}$ Moreover, service in the national armed forces by citizens of KwaZulu/Natal can only be 'on a voluntary basis' 36 - that is to say, the national government

28 The constitution is careful to protect the states' right to maintain militia forces, see US Constitution, art I, s 8, cl 16; ibid amendment II. Moreover, it appears that 'the central concern of the second amendment's framers was to prevent such federal interferences with the state militia as would permit the establishment of a standing national army and the consequent destruction of local autonomy'. L Tribe American Constitutional Law 2 ed (1988) 299 n6. See also, Clinton Rossiter (ed) The Federalist No 46 (1961) 298-300.

29 Perpich v Department of Defense 110 SCt 2418, 2428 (1990).

$30 \mathrm{KwaZulu} /$ Natal Constitution, art 67(b).

31 That the absence of such a limit was important to the course of United States history is reflected in the fact that the Civil War began when Southern soldiers fired on a national fort, Fort Sumter, in South Carolina.

$32 \mathrm{KwaZulu} / \mathrm{Natal}$ Constitution, art 62.

$33 \mathrm{KwaZulu} / \mathrm{Natal}$ Constitution, art 62 . Whether KwaZulu/Natal would acknowledge the authority of the national government to find that national defence was indeed 'required' is not stated; assuming that the constitution does cede this much authority to the national government, the only method it offers the national government for enforcing its judgments may be in the KwaZulu/Natal courts! See note 27.

$34 \mathrm{KwaZulu/Natal}$ Constitution, art 98(a).

35 US Constitution art I, s 10 para 3.

$36 \mathrm{KwaZulu/Natal}$ Constitution, art 98(d). 
cannot draft citizens from KwaZulu/Natal into the national armed forces. Even in time of war, the national government evidently will not be trusted to draft citizens of KwaZulu/Natal; instead, 'KwaZulu/Natal shall conduct military proscription [sic, presumably "conscription"] through the militia to supply armed forces to the nation'. ${ }^{37}$ The United States under the Articles of Confederation similarly relied on the states to supply the nation with soldiers, ${ }^{38}$ and its experience with this system was evidently not a happy one. ${ }^{39}$ The new constitution gave the national government of the United States explicit power to 'raise and support Armies', and this power has repeatedly been implemented through the use of military drafts. ${ }^{40}$ Finally, the Federal Republic is ceded the power to 'summon the State militia' to defend the nation 'from an external enemy', ${ }^{41}$ but not, it would seem, to summon these forces to defend the nation against internal rebellion - least of all, one might infer, against internal rebellion in KwaZulu/Natal!42

Not content to secure a monopoly on military force within the borders of KwaZulu/Natal, the constitution also grants the state sweeping emergency powers. The constitutional regulation of emergency powers has properly been an important concern for South Africans, emerging as they are from the long night of the states of emergency of the $1980 \mathrm{~s}$, and both the South African Law Commission and the African National Congress have developed proposals which could circumscribe future emergency authority in significant ways. ${ }^{43}$ Against this background, the

37 Ibid.

38 See Articles, art IX, para 5 (describing system of obtaining 'land forces').

39 See Selective Draft Law Cases 245 US 366, 380-81 (1918).

40 US Constitution, art I, s 8, cl 12; ibid cl. 13 (Navy). Though the constitution contains no explicit authorisation of a federal draft, conscription has been used repeatedly in our history, and its constitutionality was affirmed in Selective Draft Law Cases 245 US 366 (1918). (This case found some tangential support for its conclusion in what evidently were compulsory military service laws of the Orange Free State and the South African Republic. Ibid at 378-79 n1.) As the Vietnam War era demonstrated, however, the wisdom of using this power remains very much open to debate.

$41 \mathrm{KwaZulu} /$ Natal Constitution, art 67(b)

42 The United States constitution is much less restrictive. It empowers Congress ' $t$ ]o provide for calling forth the Militia to execute the Laws of the Union, suppress Insurrections and repel Invasions'. US Constitution, art I, s 8, cl 15 . (Under modern law, moreover, the national government is not even confined to these purposes when it calls forth the state militias; by 'federalizing' these state forces, the national government becomes entitled to deploy them for any and all purposes for which regular federal troops can be used. See Perpich v Department of Defense 110 SCt 2418, 2426-30 (1990).) Moreover, although one clause of Article IV, s 4 might be read to authorise the national government to suppress 'domestic Violence' within a state only on request of the state, another section, the 'Guarantee Clause', requires the national government to 'guarantee to every State in this Union a Republican Form of Government', and this clause was invoked during the Civil War as a basis for the national government's suppression of what it viewed as rebellion by the Southern states. See $\mathbf{R}$ Rotunda \& J Nowak Treatise on Constitutional Law: Substance and Procedure (1992) vol 2 319-20. The Civil War settled on the battlefield the proposition that the national government can subdue insurrection by states entirely without their consent.

43 See art 34(2) in South African Law Commission Interim Report on Group and Human Rights Project 58 (August 1991) at 698-9; African National Congress ANC Draft Bill of Rights (preliminary revised 
emergency provision of the KwaZulu/Natal constitution is particularly dismaying. The Governor is authorized by art 99 to declare an emergency, and to provide in the Declaration of Emergency 'a general indication of the type of emergency and ... in general terms which powers and resources of the State, of the Regions, of the municipalities or of the citizenry the Governor intends to employ to respond to the emergency, how such powers and resources are expected to be employed and for how long, and other measures and actions the Governor intends to undertake' ${ }^{44}$ There is no substantive limit on what powers and resources the Governor may employ, other than the pious declaration that emergency action must respect constitutional rights 'to the fullest extent possible under the circumstances'. ${ }^{45}$

There is, to be sure, a procedural limit, namely that the Governor must obtain the ratification of the General Assembly, or in their absence the approval of the Constitutional Court. ${ }^{46}$ Moreover, the General Assembly or the Court 'may terminate or modify the terms of the Declaration of Emergency at any time' ${ }^{47}$ But whatever confidence these safeguards might otherwise offer (and obviously that confidence is no greater than the likely independence of KwaZulu/Natal legislators or judges from executive domination), their efficacy is seriously undercut by the Governor's power to require that these other bodies consider emergency matters only 'behind closed doors', and to insist 'that the contents of the Declaration of Emergency be kept secret'. ${ }^{48}$ Article 99, in short, authorises the Governor to make, and enforce, secret law.

In other, more prosaic, ways, this constitution pursues its concern with limiting the power of the national government, and enhancing the power of the new state of KwaZulu/Natal. The constitution converts all property held by the national government in KwaZulu/Natal into property of KwaZulu/Natal - and does so without any apparent compensation to the citizens of the nation whose collective investment has just been taken by the citizens of a single state. ${ }^{49}$ Probably an even greater interference with

version) (1993), arts 18-23; S Ellmann 'A Constitution for All Seasons: Providing Against Emergencies in a Post-Apartheid Constitution' (1989) 21 Columbia Human Rights LR 163; N Haysom 'States of Emergency in a Post-Apartheid South Africa' (1989) 21 Columbia Human Rights LR 139. See generally, S Ellmann In a Time of Trouble: Law and Liberty in South Africa's State of Emergency (1992).

$44 \mathrm{KwaZulu} /$ Natal Constitution, art 99(a).

$45 \mathrm{KwaZulu} / \mathrm{Natal}$ Constitution, art 99(d).

$46 \mathrm{KwaZulu} / \mathrm{Natal}$ Constitution, art 99(a). If neither the General Assembly nor the Constitutional Court can be convened, fallback procedures are also provided. Ibid. It deserves mention that this section does not make clear that affirmative ratification or approval is required; it might be that inaction by the legislature or the court would suffice.

$47 \mathrm{KwaZulu} /$ Natal Constitution, art 99(c).

$48 \mathrm{KwaZulu} / \mathrm{Natal}$ Constitution, art $99(\mathrm{c})$.

$49 \mathrm{KwaZulu} / \mathrm{Natal}$ Constitution, art 109. This taking without compensation is especially striking since all other expropriations of property are 'subject to the prompt payment of a fair market value compensation'. Ibid art 35. 
national power is the constitution's imposition of drastic limits on national taxation, a central power of the federal government in the United States ${ }^{50}$ and, as noted earlier, a central area of inadequate authority under the Articles of Confederation. Simply put, the national government cannot tax within KwaZulu/Natal except 'with the advice and consent of the State of KwaZulu/Natal'. ${ }^{51}$ Moreover, this consent is to be rendered by the 'Joint Commissions [sic] on Finance of the General Assembly',52 and according to art 67(e) the Joint Commission is only required to meet 'at least once every two years' to advise the national government 'on the type and extent of Federal taxation and revenue collection permitted in the State of KwaZulu/Natal' ${ }^{53}$ In case this structure is not awkward enough, the same section goes on to say that '[a]ny resolution adopted by the Joint Commission on Finance in this respect shall have effects [sic] only in the second calendar year following the year in which the resolution is adopted' ${ }^{54}$ Suppose, then, that the national government were in 1994 to signify its desire to tax property in KwaZulu/Natal. Perhaps the Joint Commission has already met in 1994 before this decision by the national government. In that case, it need not

50 See US Constitution, art I, s 8, cl 1; amendment XVI (income tax).

$51 \mathrm{KwaZulu/Natal}$ Constitution, art 67(d).

$52 \mathrm{KwaZulu/Natal}$ Constitution, art 67(d).

$53 \mathrm{KwaZulu/Natal} \mathrm{Constitution,} \mathrm{art} \mathrm{67(e).} \mathrm{The} \mathrm{Joint} \mathrm{Commission} \mathrm{(or} \mathrm{'Joint} \mathrm{Commissions',} \mathrm{as} \mathrm{art} \mathrm{67(d)}$ would have it) is a mysterious body. No other provision of the constitution appears to refer to it, or to provide for its composition. Article 67(d) provides, however, that for the purpose of dealing with issues of federal taxation the 'Joint Commissions' will be 'chaired . . . by the Governor and integrated with six additional members with voting rights representing trade, industry and labour and nominated by the Speaker of the House and appointed by the Governor'. (According to art 67(e), representatives of the national government can also participate, but without voting rights.) Since the total size of the Commission is not provided, it is impossible to say just how much power over the question of federal taxation has been delegated by this section to unelected representatives of 'trade, industry and labour'. It is also unclear just how many representatives each of the three identified interest groups - trade, industry and labour - will have. It seems plausible, however, to infer that each of these three groups is intended to have two representatives, and if this is so, then it follows that business (trade and industry) will have better representation than labour.

Such overrepresentation of business interests would be entirely in keeping with this constitution's remarkable pattern of providing for representation of business, but not of unions, on a series of important appointive commissions. See arts 82 (Privatization Commission, two members to be appointed by the Chamber of Commerce); 90 (Civil Service Commission, two members to be appointed by the Chamber of Commerce and four by 'representatives of consumer groups'); 92 (Regulatory Relief Commission, two members to be appointed by the Chamber of Commerce, two by 'representatives of industry', and two by representatives of consumer groups); 94 (Environmental Commission, two members to be appointed by the Chamber of Commerce and four by 'representatives of environmental groups'); 95 (Consumer Affairs Commission, two members to be appointed by the Chamber of Commerce and four by representatives of consumer groups); 112 (Transitional Electoral Commission, two members appointed by the Chamber of Commerce and two by the bar association). The only exceptions to this pattern are in arts 93 (Economic Development Commission, two members appointed by the Chamber of Commerce, two by representatives of consumer groups and two by 'representatives of the trade unions') and 106(a) (Commission on Regionalization, three members each to be appointed by representatives of 'the trade, industry and labour').

$54 \mathrm{KwaZulu/Natal}$ Constitution, art 67(e). 
meet again in 1994, or at all in 1995, so it would not have to convene to consider the national government's desire until 1996. In 1996, then, the Joint Commission might adopt a resolution approving of this federal taxation (or it might not). If it did give its approval, then the national government could actually impose taxes - in 1998!

Having limited both the weapons and the financial resources available to the federal government, the KwaZulu/Natal constitution also seeks to circumscribe the sphere of national authority. Article 67(a) sets out a list of national powers which KwaZulu/Natal 'recognizes', dealing with matters including international relations and external defence, foreign trade, air and sea law, intellectual property, the monetary system, and 'general principles of legislation to coordinate' a variety of fields such as environmental issues, interstate commerce, and communication. 55 Broadly speaking, the function of the national government according to the KwaZulu/Natal constitution will be to handle foreign affairs and provide basic ground rules and coordination for domestic life. These are not trivial functions -indeed, they bear considerable resemblance to the functions that the framers of the United States constitution intended to confer on the national government of the United States in the late eighteenth century - but they are also far from plenary national authority, and similarly far from the authority the United States government actually wields today. For example, there is no recognition of a federal power to spend for the general welfare, a power that has been an important part of the authority of the national government in the United States ${ }^{56}$ - and indeed any such spending will be decidedly confined by the limits on the federal power to tax.

To an American, the limits on the national government's power over interstate commerce are also particularly significant. In the United States, the constitutional grant of authority for the nation to regulate commerce between the states has grown into a source of vast authority over the nation's affairs, as the rise of a modern economy has made virtually everything in some way connected to interstate commerce. ${ }^{57}$ The KwaZulu/Natal constitution is obviously concerned to prevent just this result, although it may not have found the words to accomplish its goal. Thus it 'recognizes' exclusive national authority to enact 'general principles of legislation to coordinate economic development and foster

$55 \mathrm{KwaZulu} /$ Natal Constitution, art 67(a).

56 See US Constitution, art I, s 8, cl 1. The modern, expansive interpretation of this power stems from Steward Machine Co. v Davis 301 US 548 (1937).

57 See US Constitution, art I, s 8, cl 3. After a shifting series of decisions on the scope of this power, the Supreme Court abruptly and dramatically endorsed a broad interpretation of its reach in cases during the New Deal. See, eg National Labor Relations Board v Jones \& Laughlin Steel Corp. 301 US 1 (1937). For an instance of the modern application of the commerce clause, see Heart of Atlanta Motel $v$ United States 379 US 241 (1964) (upholding a statute prohibiting racial discrimination in motels and other public accommodations, on the ground that such discrimination affected interstate commerce). 
interstate commerce among the states'. ${ }^{58}$ Plainly these 'general principles' are not meant to cover every aspect or detail of interstate commerce, for the same section also recognizes exclusive national power to legislate 'to provide negotiation and procedural coordination of the State's policies with national policies and the policies of other states in the field [sic] of transportation, energy, interstate and foreign commerce, economic development, consumer protection, banking and social welfare in so far as they relate to the interests of the Federal Republic of South Africa' ${ }^{59}$ Modern American commerce clause doctrine would suggest that this limit is no limit at all, because everything relates to the interests of the nation - but surely that notion is not what lies behind the adoption of this language in this document. One particularly striking illustration of this document's sense of what the scope of state as opposed to national concerns might be, can be found in art 81 which mandates the establishment of '[a]n autonomous Central Bank of the State of KwaZulu/Natal', to be 'independent within the parameters of the law to use tools of monetary intervention in the public interest'. ${ }^{60}$ Apparently KwaZulu/Natal may have, in some measure, its own monetary policy!61

Finally, it is important to mention one other missing power: an authority, akin to that vested in the national government of the United States by the Reconstruction Amendments, ${ }^{62}$ to protect the constitutional rights of the citizens of the nation. No such general power is spelled out in the KwaZulu/Natal constitution. The availability of such authority has proven very important to the protection of constitutional rights in the United States, but even without this precedent the failure to vest this power in the national government of a post-apartheid South Africa would be remarkable. Surely the government of a new South Africa, if it is charged with no other responsibility, will at least be expected by most citizens of the new nation to root out racial discrimination. If the $\mathrm{KwaZulu/Natal} \mathrm{constitution} \mathrm{were} \mathrm{to} \mathrm{become} \mathrm{the} \mathrm{model} \mathrm{for} \mathrm{South} \mathrm{Africa's}$ governmental structure, however, the national government could only play this part on consent of the states, or, in the constitution's words, 'as authorized by a constitutional law of the State of KwaZulu/Natal'. ${ }^{63}$

$58 \mathrm{KwaZulu} /$ Natal Constitution, art 67(a).

59 Ibid (emphasis added).

$60 \mathrm{KwaZulu} /$ Natal Constitution, art 81.

$61 \mathrm{KwaZulu} / \mathrm{Natal}$ will not have complete monetary independence, for art 67(a) recognizes exclusive federal authority over the 'monetary system' and 'general principles of legislation to coordinate the regulation of banking, credit and insurance', Nonetheless the existence of art 81 seems emblematic of this constitution's desire to identify areas of state prerogative even within such fields of intensely national concern as the regulation of the monetary system.

62 See text at note 13.

$63 \mathrm{KwaZulu} / \mathrm{Natal}$ Constitution, art 67(b). Perhaps a 'rights-enforcing' role for the federal government can be found implicit among the other powers recognized in this section, but the language of the section does not make such inference easy. Nor is it apparent why, if such a power were meant to be acknowledged, this intention would not have been spelt out 
All of this, according to the constitution itself, will 'come into force the day of [the constitution's] ratification by a referendum approving this constitution with at least fifty one percent of the votes validly cast ${ }^{\prime} 64$ though Chief Buthelezi has affirmed his desire to negotiate a solution to South Africa's constitutional debates rather than to 'go it alone'. ${ }^{65}$ The result would be a national government hobbled, and a state government exalted in its powers. Perhaps this result in some measure reflects consociationalist thinking, with its dread of majoritarian power and its hope for government through enlightened cooperation among groups whose separate prerogatives are firmly entrenched. I do not believe that South Africa is so divided that it must turn to consociationalism, and so abandon the engine for reform and reconstruction that a stronger national government can provide. It is accepted on all sides, however, that some limits on the authority of the national government will be needed, and well-designed federalist structures offer one framework for establishing those limits. Whether South Africans should adopt a federal system to govern a post-apartheid nation is a complex question, and one that will probably not be finally settled at least until a constituent assembly completes its work. But those who might find a federal system attractive, and who might find support for the federalist idea in the constitution of the United States, should not be misled by the KwaZulu/ Natal constitution's effort to claim the mantle of federalism. This constitution's 'federalism' was rejected by the United States two centuries ago - and for good reason.

$64 \mathrm{KwaZulu} / \mathrm{Natal}$ Constitution, art 112. This provision means that opponents of this constitution who decide to boycott the referendum will actually be reducing the total number of votes required for its ratification. Once in place, moreover, this constitution will not be easy to amend. An extremely ambiguous provision directs that all rights 'inherent to fundamental human needs and aspirations . . . as they will be recognizable on the basis of the principles underlying the provisions of this constitution, are hereby entrenched in this constitution and in their essential content may not be modified by virtue of constitutional amendments'. Ibid art 29. Even those amendments that can be made will require approval by two thirds of the members of both houses of the General Assembly, and approval by 'the absolute majority of votes cast in a popular referendum'. Ibid ant 104.

It deserves mention that the members of the Senate, one of the two houses of the General Assembly whose approval will be necessary for any amendments to the constitution, will be chosen by a process which will not have to comply with one-person, one-vote principles. (The Senate's concurrence will also generally be necessary for the passage of ordinary legislation. See ibid art 71 (semble).) The Senate's members will come from Regions, either by popular election within the Regions (for two-thirds of the Senators) or by selection by the Regional Congresses (for one-third of the Senators). Ibid art 69(c). The Regions are to be set up with a view, inter alia, to 'ensur[ing] a proper and just balance amongst the various parts of the State's territory', Ibid art 106(c), but there is no requirement that they be equal in population. It is also not clear whether the members of the Regional Congresses, which will elect one-third of the national Senators, must themselves be elected from constituencies of equal population. See ibid art 83(c).

65 Speaking in Pretoria's City Hall, Chief Buthelezi reportedly said that '[t]he KwaZulu/Natal state constitution would be offered for acceptance in the negotiation process as a constitution for a state in a federal South Africa if approved by people in the region through a referendum'. Buthelezi declared that 'we would be quite prepared to negotiate about how we relate to other states in South Africa and what the composition and powers of the federal government should be'. British Broadcasting Corporation, Summary of World Broadcasts 'Inkatha Leader Proposes Constitution Based on Federation of States', SAPA dispatch datelined Pretoria, 8 December 1992 (available on NEXIS). 